\title{
How Informative Are Stock Prices of Islamic Banks?
}

\author{
Pejman Abedifar ${ }^{\mathrm{a}, 1}$, Kais Bouslah ${ }^{\mathrm{a}}$, Shatha Qamhieh Hashem ${ }^{\mathrm{b}}$, Liang Song ${ }^{\mathrm{c}}$ \\ ${ }^{\text {a }}$ Centre for Responsible Banking \& Finance, School of Management, University of St Andrews, UK \\ ${ }^{\mathrm{b}}$ Department of Financial \& Banking Sciences, An-Najah National University, Nablus, Palestine \\ ${ }^{\mathrm{c}}$ University of Massachusetts Dartmouth, USA
}

22 February 2020

\begin{abstract}
Using a sample of 2,210 observations for 170 banks operating in 12 countries with dual banking systems over 2005-2017 period, we find that Islamic banks have lower stock return non-synchronicity, lower illiquidity ratio, and their current returns have lower future earnings prediction ability than conventional banks. The results hold for the GCC-member countries and in the non-crisis period. Hence, Islamic banks in such countries have less information content in stock prices than conventional banks that can be due to their lower degree of transparency mandated by their financial paradigm. This suggests that for Islamic banks, market discipline may not be as effective as it is for conventional banks and hence they require more direct supervision. The finding has important implications for policymakers in countries with dual banking systems.
\end{abstract}

JEL Classifications: G12, G14, G21, G30, M41

Keywords: Stock Return Non-Synchronicity; Stock Illiquidity; Future Earnings Prediction Ability; Islamic Banking

Acknowledgement: This paper was presented at the 2018 Cross Country Perspectives of Finance (CCPF) conferences held in Guangzhou, China and Dar es Salaam, Tanzania. We would like to thank Iftekhar Hasan, Yueh-Neng Lin, seminar participants of the CCPF conferences and two anonymous referees for their constructive comments. Any remaining errors are our own.

${ }^{1}$ Corresponding author. E-mail addresses: pa31@st-andrews.ac.uk (P. Abedifar); kbhb@st-andrews.ac.uk (K. Bouslah); shatha.qamhieh@najah.edu (S.Q. Hashem); 1song@umassd.edu (L. Song). 
'Declarations of interest: none'.

'This research did not receive any specific grant from funding agencies in the public, commercial, or not-for-profit sectors'. 


\title{
How Informative Are Stock Prices of Islamic Banks?
}

\author{
22 February 2020
}

\begin{abstract}
Using a sample of 2,210 observations for 170 banks operating in 12 countries with dual banking systems over 2005-2017 period, we find that Islamic banks have lower stock return non-synchronicity, lower illiquidity ratio, and their current returns have lower future earnings prediction ability than conventional banks. The results hold for the GCC-member countries and in the non-crisis period. Hence, Islamic banks in such countries have less information content in stock prices than conventional banks that can be due to their lower degree of transparency mandated by their financial paradigm. This suggests that for Islamic banks, market discipline may not be as effective as it is for conventional banks and hence they require more direct supervision. The finding has important implications for policymakers in countries with dual banking systems.
\end{abstract}

JEL Classifications: G12, G14, G21, G30, M41

Keywords: Stock Return Non-Synchronicity; Stock Illiquidity; Future Earnings Prediction Ability; Islamic Banking

'Declarations of interest: none'.

'This research did not receive any specific grant from funding agencies in the public, commercial, or not-for-profit sectors'. 


\section{Introduction}

Financial systems play a pivotal role in the economy. A well-functioning financial system facilitates mobilization of resources, collection and processing of information, allocation of resources to profitable projects and exertion of corporate control (Levine, 1997). The extant literature shows that financial markets can influence the real side of the economy through information channels, because securities' prices can convey aggregate information possessed by outsiders, and corporate management can use such information to make better decisions (e.g., Dow and Gorton, 1997; Subrahmanyam and Titman, 1999).

Previous studies underscore the fact that financial systems with different structures can have different impacts on the economy (Levine, Loayza and Beck, 2000; Beck and Levine, 2004). In several Muslim countries, the banking system has been transformed following the introduction of Islamic banking. Extant literature have shown differences between Islamic banks vis-à-vis conventional banks in various aspects such as credit risk (Abedifar, Molyneux and Tarazi, 2013; Baele Farooq and Ongena, 2014), cost inefficiency (Al-Jarrah and Molyneux, 2005; Beck, Demirguc-Kunt and Merrouche, 2013; Alqahtani, Mayes and Brown, 2017), insolvency risk (Cihak and Hesse, 2010), failure risk (Alandejani, Kutan and Samargandi, 2017), market power (Weill, 2011) and systemic risk (Abedifar, Giudici and Hashem, 2017). In addition, Shaban, Duygun, Anwar and Akbar (2014) and Aysan, Disli, Ng and Ozturk (2016) show that Islamic banks are more likely to grant loans to small firms, which are generally excluded by conventional banks due to their opacity and absence of collateral ${ }^{1}$. Athari, Adaoglu and Bektas (2016) and Grira, Hassan, Labidi and Soumaré (2019) find that information asymmetry problem is more severe for Islamic banks than conventional banks. In this paper, we

\footnotetext{
${ }^{1}$ They study Islamic banks in Indonesia and Turkey, respectively.
} 
extend this literature by investigating differences between Islamic and conventional banks in terms of stock price informativeness. This is worthwhile to explore, because it can contribute to better understanding of how to effectively supervise the banking industry in countries with dual banking systems, where both Islamic banks and conventional banks operate.

The use of market discipline as a complement to regulation and supervision for stability of banking system is widely recognized and accepted (Meyer, 1999; Federal Reserve Study Group on Disclosure, 2000; Greenspan, 2001). Effectiveness of market discipline, however, depends on access to information about riskiness of banks' assets (Greenspan, 2001). The information helps market participants discipline bank managers, e.g., outside investors price bank' stocks more accurately given their adequate information about bank-risk taking behavior (Federal Reserve Study Group on Disclosure, 2000). In this way, more stock price informativeness complements bank regulation toward a more safe and stable banking system (Jones, Lee and Yeager, 2012). In practice, however, stock price informativeness varies across banks and countries, which implies that the degree of reliance on market discipline to contain risk-taking behavior of banks varies accordingly. Therefore, it is imperative for regulators of dual banking systems to understand whether Islamic banks have less information content in their stock prices than conventional banks.

On the one hand, since Islamic finance is asset-based, Islamic banking is more connected to the real economy, and therefore their market prices are expected to transmit the information to the management more effectively. In addition, one could argue that Islamic banks must be more transparent because they should ensure their clients and investors that they are provided with Sharia-compliant financial products which necessitates having an additional layer of governance 
called "Sharia Supervision Board" to avoid fiduciary risk in their operations (Mollah and Zaman, 2015).

On the other hand, the presence of the Sharia Supervision Board in the corporate governance structure of Islamic banks can make their operation more complex than that of conventional banks, because in such banks, new financial products and instruments must be assessed and approved by this board, in addition to legal and risk management departments (Farag, Malin and Ow-Yang, 2018). Moreover, Islamic banks provide credit to their clients through complex financial products, which along with lack of adequate knowledge of general investors about Islamic banks' operations, and a relatively low level of financial disclosure and reporting (Atmeh and Ramadan, 2012; Abdullah, Percy and Stewart, 2015; AlShattarat and Atmeh, 2016), may slow down incorporation of information into stock prices ${ }^{2}$ and raises an important question that whether their stock prices are less informative than those of conventional banks.

Empirically, we attempt to achieve our objective by taking the following steps. First, we compare stock returns non-synchronicity of Islamic vis-à-vis conventional banks. This measure was proposed by Roll (1988). A large body of empirical studies show that stocks with greater comovements with the market return convey less firm-specific information, and hence a higher return non-synchronicity represents a higher price informativeness (see e.g., Morck, Yeung and

\footnotetext{
${ }^{2}$ Price informativeness reflects the extent to which stock prices carry idiosyncratic information (Morck et al., 2000). Alternatively, price informativeness reflects how much information about future earnings is capitalized into current stock prices (Durnev et al., 2003). The empirical literature shows a significantly negative association between price informativeness and incomplete information (i.e., asymmetric information) where outside investors do not or cannot have access to all or part of firm-specific information (Veldkamp, 2006; Blau et al., 2017). Informed trading capitalizes information into stock prices (Grossman, 1976; Shleifer and Vishny, 1997; Morck et al., 2000); however, incomplete information reduces the set of informed investors and thereby lowers trading activities (Blau et al., 2017). Consequently, under an incomplete information environment, stocks do not fully impound firm-specific information. Jin and Myers (2006) develop a model showing that the division of risk-bearing between insiders and outsiders depends on the level of information asymmetry. An increase in opacity increases the exposure of insiders to idiosyncratic risk and lowers the idiosyncratic risk taken by outsiders. Such stocks tend to have a higher $\mathrm{R}^{2}$.
} 
Yu, 2000; Wurgler, 2000; Durnev, Morck, Yeung and Zarowin, 2003; Durnev, Morck and Yeung, 2004; Hasan, Song and Wachtel, 2014; and Francis, Hasan, Song and Yeung, 2015).

Second, we compare the illiquidity ratio of Islamic banks and conventional banks. This measure was introduced by Amihud (2002) and is used by several studies as a proxy of price informativeness (see e.g., Ferreira, Ferreira and Raposo, 2011 and Fresard, 2012). The illiquidity ratio measures the price impact of trading, and represents the private information impounded in stock price (Kyle, 1985; Fresard, 2012). This ratio is expected to be positively related to the quantity of informed trading on a stock. The higher the illiquidity ratio, the higher the stock price informativeness is, i.e., the stock price is tracking more closely its fundamental value.

Third, we compare the strength of current stock returns-future earnings relation for Islamic banks vis-à-vis conventional banks. This measure was introduced by Collins, Kothari, Shanken and Sloan (1994), and further developed by Lundholm and Myers (2002). Specifically, stock price informativeness is proxied by the extent to which current stock prices incorporate information about future earnings (Fernandes and Ferreira, 2008) or how much information about future earnings is embedded in current stock prices (Durnev et al., 2003). If future earnings in a regression model of current returns on past, current and future earnings have a significantly positive coefficient, then the stock price incorporates more information about future earnings, i.e., it has higher price informativeness.

In this paper, we study a sample of 2,210 observations for 170 banks operating in 12 countries with dual banking systems - wherein Islamic banks and conventional banks operate over 2005-2017 timespan. The results show that Islamic banks have a lower stock price nonsynchronicity, have a lower illiquidity ratio, and their current returns have less predictive power for future earnings. Overall, the findings suggest that Islamic banks have less informational 
content in stock prices than conventional banks. Further analysis for different subsamples shows that our findings hold for the Gulf Cooperation Council (GCC)-member countries and during the non-crisis period.

This paper contributes to Islamic banking literature, in particular to the literature on performance, supervision and financial stability of dual banking systems. Earlier studies show that the heterogeneities between Islamic banks and conventional banks improve the performance of dual banking systems (Gheeraert, 2014; Gheeraert and Weill, 2015; Abedifar, Hasan and Tarazi, 2016), whereas more recent papers find that Islamic banks have higher degrees of information asymmetry than conventional banks, which imply that they require a more stringent supervision (Shaban et al., 2014; Athari et al. 2016; Aysan et al., 2016; Grira et al., 2019). Abedifar et al. (2018) examine the relationship between financial stability and architecture of dual banking systems. They show that commercial banks that provide both Islamic and conventional banking have a higher systemic risk. Their analysis suggests that from the banking system stability point of view Islamic and conventional banking must be provided through two separate institutions. Our study complements this literature by showing that Islamic banks require more direct supervision than conventional banks, because they are less transparent than their conventional counterparts and as a result market discipline may not work very well for them.

Our paper also relates to the large literature on opacity of banks, which shows that banks have more opacity than other industries (see for instance Morgan, 2002). Our results extend this literature by providing some evidence from dual banking systems in terms of difference in opacity even within the banking industry. 
The remainder of this manuscript is organized as follows: Section 2 puts forward our hypotheses. Section 3 explains our methodology and econometric specifications. Section 4 presents our sample. Section 5 discusses our results and section 6 provides concluding remarks.

\section{Hypothesis Development}

Financial markets have a pivotal role in real investment decision making by providing feedback to decision makers. Allen (1993) points out that financial markets provide firms' management with the information that they cannot obtain otherwise. However, the literature shows that prices of certain securities convey more firm-specific information, whereas prices of some other stocks mostly comove with the market and reveal less idiosyncratic information. In this paper, our objective is to contribute to an understanding of whether the information channel between the real economy and financial markets is weaker for Islamic banks relative to conventional banks. We expect a different degree of informativeness between the two types of banking, given their different business model and finance technology.

One can argue that since Islamic finance is asset-based, Islamic banking is more connected to the real economy, and therefore their market prices can transmit the information to the management more effectively. In addition, Islamic banks could be more transparent because they should ensure their clients and investors that they are provided with Sharia-compliant financial products which necessitates having an additional layer of governance called "Sharia Supervision Board" to avoid fiduciary risk in their operations (Mollah and Zaman, 2015).

However, Islamic banks use rather complex lending technologies and financial instruments $^{3}$ that can exacerbate asymmetric information problem, and slow down incorporation

\footnotetext{
${ }^{3}$ This does not imply that the quality of Islamic banks' assets is inferior relative to conventional banks. Indeed, several studies find that Islamic banks have a relatively lower credit risk (Baele et al., 2014; Abedifar et al., 2013).
} 
of information into the market prices. They provide credit to their clients through trade contracts in lieu of loan agreements. For instance, for a simple debt-based finance contract such as Murabaha, an Islamic bank purchases the product and then resells it to the client on credit. For purchasing the product in the market, the Islamic bank appoints the client as its agent in order to avoid a real trade transaction. Since ownership of the product bears some risk for the owner, the client must take necessary steps in order to keep the Islamic bank in the safe side. Islamic banks face other restrictions in their business, for instance, they cannot use interest-bearing securities. Instead, they should use Sharia-compliant financial assets such as sukuk. Moreover, Islamic financial products have dual characteristics, because they should comply with both Sharia (Islamic law) and local laws and legislation. As a result, they have Sharia Supervisory Board in the corporate governance to ensure compatibility of financial instruments with Sharia. El-Gamal (2008) claims that Islamic finance jurisprudence follows pre-modern jurisprudence, and hence it is not perfectly compatible with today's financial engineering.

Several strands of literature underscore opacity and complexity of Islamic banking. The literature on market funding points out that the complexity of sukuk exacerbates information asymmetry problem (Godlewski, Turk-Ariss and Weill, 2013; Klein and Weill, 2016). Van Wijnbergen and Zaheer (2013) study defaults under sukuk and point out that apart from Sharia, investors should consider the legal framework of the country where the underlying assets and collateral can be contested. El-Gamal (2005) argues that in order to make the product permissible, Islamic banks should separate their clients from the underlying conventional products, for instance by creating a special purpose vehicle (SPV) to convince their clients that they provide Islamic financial services from a separate source of funds other than conventional sources, or by signing two separate sale contracts in order to convince Islamic jurists that the 
product is in compliance with Sharia. Kyriakos-Saad, Vasquez, El Khoury and El Murr (2016) point out that Islamic financial products are designed based on an underlying asset, which brings a layer of complexity.

Accounting literature underscores the importance of financial disclosure for Islamic banks, given the nature of profit and loss sharing paradigm, and the distinctive relationship of Islamic banks with their investment account holders (Sundararajan and Errico, 2002; Al-Baluchi, 2006). However, several studies show that Islamic banks have a relatively poor disclosure in relation to investment account holders (Srairi, 2015; Sulaiman et al., 2015) ${ }^{4}$. Abdullah et al. (2015) investigate corporate governance practices of a sample of Islamic banks and argue that the specific risks inherent in Islamic banking necessitate greater corporate governance disclosure. Their analysis shows that voluntary governance disclosure of Islamic banks is relatively low. Uddin, Kabir and Mollah (2017) show that earnings of Islamic banks are, on average, more uncertain than those of conventional banks.

Since the literature on stock price informativeness illustrates that higher information asymmetry decelerates incorporation of idiosyncratic information into stock prices (Morck et al., 2000; Jin and Myers, 2006), we argue in this paper that stock returns of Islamic banks convey less firm-specific information than those of conventional banks. We attribute this prediction to the higher information asymmetry of Islamic banks relative to that of conventional banks. This implies that the costs associated with opacity and complexity of lending technologies of Islamic banks along with the low level of knowledge and understanding of general investors about

\footnotetext{
${ }^{4}$ Sulaiman, Majid and Arifin (2015) examine the disclosure quality of 16 Islamic financial institutions in Malaysia and find a very low level of disclosure on information pertaining to customers and investment account holders. Srairi (2015) studies 27 Islamic commercial banks in 5 countries in the Middle East and finds that Islamic banks disclosure in relation to investment account holders is below the Accounting and Auditing Organization for Islamic Financial Institutions (AAOIFI) disclosure requirement.
} 
Islamic banks' contracts and inadequate financial disclosure by Islamic banks outweigh the benefits associated with their connection to the real economy. We examine stock price informativeness of Islamic banks relative to their conventional counterparts using three proxies: non-synchronicity, illiquidity ratio and predictive power of current returns. This enables us to empirically test the following three hypotheses:

Hypothesis 1: Islamic banks have a lower stock price non-synchronicity.

Hypothesis 2: Islamic banks have a lower illiquidity ratio.

Hypothesis 3: Current returns of Islamic banks have less predictive power for future earnings.

\section{Methodology and Econometric Specifications}

\subsection{Banks Stock Return Non-Synchronicity and Price Informativeness}

Stock return non-synchronicity refers to the variation in the stock return that is idiosyncratic, i.e., not explained by the market or industry returns ${ }^{5}$. This unexplained firm-specific return variation may convey private information revealed by speculative traders (Grossman and Stiglitz, 1980; Glosten and Milgrom, 1985 and Kyle, 1985). The stock return non-synchronicity as a measure for capturing firm private information was firstly introduced by Roll (1988), and later on was improved by Morck et al. (2000), Durnev et al. (2003), and Durnev et al. (2004). The main idea is that idiosyncratic return variations of a stock are correlated with the private information of traders, who have no communication with the firm other than their trades in the financial market. A large body of literature shows that stock return non-synchronicity is positively related to price informativeness (Morck et al., 2000; Durnev et al., 2003; Wurgler, 2000; Durnev et al., 2004;

\footnotetext{
${ }^{5}$ Market data analysis is generally based on market efficiency assumption. In this study, however, violation of this assumption cannot jeopardize our methodology, because market inefficiency affects both conventional and Islamic banks, and therefore any difference in price informativeness is not due to market inefficiency, but it is rather attributed to the nature of Islamic banking.
} 
Hasan et al., 2014; Francis et al., 2015) and represents higher transparency (Jin and Myers, 2006).

Stock return non-synchronicity is commonly measured using R-squared of a standard regression model. The bank specific return variation is calculated as Non_SYNCHRO ${ }_{i}=$ $\operatorname{Ln}\left(\left(1-R^{2}\right) / R^{2}\right)$, where $R^{2}$ is estimated from the following regression:

$r_{i t}=a_{i}+b_{i B} r_{B t}+b_{i m} r_{m t}+\varepsilon_{i t}$

where $r_{i t}$ is the return of bank $i$ at time $t, r_{B t}$ is the return of the banking industry at time $t$, and $r_{m t}$ is the return of the market $m$ at time $t$. The return of banking industry is calculated without including bank $i$.

We use the following multivariate regression equation in order to compare stock price non-synchronicity of Islamic banks vis-à-vis conventional banks.

Non_SYNCHRO $O_{i t}=b_{0}+b_{1}$ Islamic_ $_{i t}+\delta X_{i t}+\gamma$ countryFE $+\alpha y e a r F E+\varepsilon_{i t}$

In Equation (2), we regress price informativeness proxy (Non_SYNCHRO ${ }_{i t}$ ) obtained from Equation (1) on Islamic banks' dummy (Islamic_D $D_{i t}$ ) and a set of control variables. We consider conventional banks as the base group. We include a vector $\left(X_{i t}\right)$ for bank specific and country specific variables. Bank specific factors include logarithm of total assets (size), growth rate of total assets (asset_growth), ratio of non-interest expense to net operating income (inefficiency), financial leverage (leverage), the ratio of non-performing loans to net loans (nploans), ownership structure (captured by two dummy variables for foreign and stateownership, where domestic private ownership is set as the control group) and a dummy variable to represent cross-listing. Country specific factors include growth of GDP per capita 
(GDP_growth) and domestic interest rate (interest_rate). countryFE and yearFE represent country fixed effects and year fixed effects, respectively.

Size (-): Firm size is expected to be negatively related to price informativeness. First, it is more difficult to analyse larger firms, because they are more complicated (Durnev et al., 2003). Francis et al. (2015) find that larger banks have lower price informativeness, because they have larger credit portfolios covering many firms and industries, which implies that stocks of larger banks align more with the market. Second, larger firms might act as a leading market indicator of the whole economy trends, and therefore their stocks induce similar overall market movements, i.e., stocks of larger banks align more with the whole market (Piotroski and Roulstone, 2004). Several studies provide empirical evidence that supports a negative relationship between firm size and price informativeness (e.g., Durnev et al., 2001; Durnev et al., 2003; Piotroski and Roulstone, 2004; Dasgupta et al., 2010).

Asset growth (+): We use asset growth as a proxy for growth opportunities which could affect price informativeness through earnings timeliness ${ }^{6}$ (Durnev et al., 2003). Banks with higher growth opportunities have less timely earnings, e.g., there is a more significant relationship between their current returns and future earnings. Consistent with this prediction, Chan, Fengfei, Lin and Lin (2017) find a significantly positive correlation between the growth rate of total assets and current stock returns. Therefore, we expect asset growth to have a positive relationship with price informativeness.

\footnotetext{
${ }^{6}$ Earnings timeliness refers to the timely incorporation of value relevant information (e.g., bad and good news) in current earnings (Basu, 1997; Durnev et al. 2003). Timeliness represents the value relevant information recognized (incorporated) in current earnings (i.e., reported in current earnings). Alternatively, more timely earnings imply that current earnings reflect all value-relevant information. Please note that the information could already have been incorporated into stock price, but not recognized (incorporated) yet in current earnings. In this case, the information will be recognized (incorporated or reported) in future earnings.
} 
Inefficiency (-): We use the ratio of non-interest expense to net income as a proxy of bank cost inefficiency (Inefficiency). Inefficiency represents banks' quality of management (Assaf, Berger, Roman and Tsionas 2019). Therefore, we expect stock prices of more efficient banks to be more informative, in other words, we expect Inefficiency to be negatively associated with stock price informativeness.

Bank risk could also affect price informativeness. Risk is associated with more volatile earnings, which is positively linked to price informativeness (Dasgupta et al., 2010). Moreover, previous literature shows that bad news is incorporated into stock prices more quickly than good news (Basu, 1997; Durnev et al., 2003). Investors are very sensitive to bad news (e.g., losses) than to good news (e.g., gains). This asymmetric reaction of investors due to loss aversion is extensively examined in the finance literature (Thaler, Tversky, Kahneman and Schwartz, 1997; Bekaert and Wu, 2000 among others). Jin and Myers (2006) find that firms with lower firm-specific risk have higher stock price synchronicity (i.e. lower price informativeness). In this study, we use bank financial risk (Leverage) and bank credit risk (Non-performing loans) as bank risk indicators, because banks with higher Leverage and/or Non-performing Loans are perceived to be riskier. Therefore we include Leverage (+) and Non-performing Loans (+) in our analysis, and we expect a positive relationship between price informativeness and these two indicators of risk.

Ownership structure (+/-): Ownership structure can influence banks' stocks price informativeness. State-owned banks are expected to have lower transparency and price informativeness, because they do not generally have strong corporate governance and are expected to be strongly influenced by macroeconomic policies of governments (Francis et al., 2015). Consequently, they have less idiosyncratic variations in fundamentals, and lower informed risk arbitrage, i.e., less informed stock prices. Bonin et al. (2005) show that foreign- 
owned banks are more efficient than other banks in transition economies and they provide better services. Hence, we expect that stock prices of foreign-owned banks to be more informative than other banks. We classify banks into three groups: privately-owned banks, foreign-owned banks and state-owned banks. Privately-owned banks are used as the benchmark, and therefore we include two dummy variables for state-owned banks and foreign-owned banks in our model.

Cross-listing (+): stock prices of cross-listed banks are expected to be more informative due to the disclosure requirements of listing exchanges. Fernandes and Ferreira (2008) find that stock prices of cross-listed firms are more informative, because cross-listing provides a wider array of informed investors. Hence, we include a dummy variable, which takes the value one for crosslisted banks.

Country specific variables: We follow Jones, Lee and Yeager (2013) and capture cross-country variations by including GDP growth and domestic interest rate. Finally, we control for year fixed effects by adding 12 dummies for the years 2006-2017 to our model. We consider year 2005 as the benchmark.

\subsection{Illiquidity Measure and Stock Price Informativeness}

In this sub-section, we gauge stock price informativeness of Islamic banks vis-à-vis conventional banks by using the illiquidity ratio (illiq). This measure was introduced by Amihud (2002) and is widely used to represent stock price informativeness in several studies (e.g., Ferreira et al., 2011 and Fresard, 2012). It is computed as the annual average of the weekly ratio between the stock return absolute value and the stock trading volume in dollars (multiplied by $10^{6}$ ). It measures the stock absolute return per dollar of weekly trading volume. The illiquidity ratio is considered as an approximation for the price impact of trades, which is positively related to the quantity of informed trading of a stock (Kyle, 1985; Fresard, 2012). The illiquidity ratio has a positive 
relationship with private information impounded in stock prices (Fresard, 2012; Fernandes and Ferreira, 2008). In other words, higher illiquidity ratio implies higher stock price informativeness. The illiquidity ratio (illiq) is calculated as:

$i l l i q_{t}=\frac{1}{D_{i}} \sum_{t=1}^{D_{i}} \frac{\left|r_{i t}\right|}{\text { dtVol } l_{i t}}$

where $D_{i}$ is the number of weeks for bank $i$ with valid observations during the given period, $\left|r_{i t}\right|$ is firm $i$ stock return absolute value at time $t$, and $d t V o l_{i t}$ is the dollar trading volume of bank $i$ at time $t$.

We use the following multiple regression equation in order to compare the illiquidity ratio of Islamic banks vis-à-vis their conventional counterparts.

illiq $_{i t}=b_{0}+b_{1}$ Islamic $_{-} D_{i t}+\delta X_{i t}+\gamma$ countryFE $+\alpha$ yearFE $+\varepsilon_{i t}$

In Equation (4), we regress the illiquidity measure ( $i l l i q_{i t}$ ) obtained from Equation (3) on Islamic banks' dummy (Islamic_D), a set of control variables $X_{i t}$, countryFE and yearFE as outlined in Equation (2) above.

\subsection{Banks' future earnings level and Stock Price Informativeness}

In this sub-section, we compare the strength of current stock returns-future earnings nexus for Islamic vis-a-vis conventional banks. The accounting literature suggests an alternative measure of stock price informativeness based on the relationship between current stock returns and future earnings (Collins et al., 1994; Lundholm and Myers, 2002; Durnev et al., 2003). More specifically, "the ability of current stock returns in tracking future earnings is a measure of stock

price informativeness" (Durnev et al., 2003, p. 802). In other words, stock price informativeness is proxied by the extent to which stock price incorporates information about future earnings (Fernandes and Ferreira, 2008) or how much information about future earnings is incorporated in 
stock prices (Durnev et al., 2003). The basic idea is that current stock return is determined by or can be decomposed into three components: unexpected current earnings, changes in expected future earnings and a random noise not related to the first two components (Lundholm and Myers, 2002). This return decomposition can be represented by a regression equation where current stock returns are regressed on unexpected current earnings, changes in expected future earnings and a random error. Since the independent variables of this regression are not observable, different proxies have been used in previous studies. In this paper, we follow the regression model suggested by Lundholm and Myers (2002) to examine the relationship between current stock returns and future earnings:

$R_{i t}=b_{0}+b_{1} E 3_{i t}+b_{2} E_{i t-1}+b_{3} E_{i t}+b_{4} R 3_{i t}+\delta X_{i t}+\alpha$ yearFE $+\gamma$ countryFE $+\varepsilon_{i t}$

wherein $R_{i t}$ represents the return for bank $i$ at year $t, E 3_{i t}$ is the future earnings, and is equal to the sum of earnings over three years: $t+1, t+2, t+3$, that are scaled by equity market value at the beginning of year $t . E_{i t-1}$ is earnings of year $t-1$ scaled by equity market value at the beginning of year $t-1 . E_{i t}$ is the current earnings in year $t$, that are scaled by equity market value at the beginning of year $t . R 3_{i t}$ is the future return over the 3 -year period that follow the current year. $X_{i t}$ is a vector of control variables for bank and country specific variables as outlined in Equation (2) above. yearFE and countryFE represent year fixed effects and country fixed effects, respectively. On the basis of the work of Lundholm and Myers (2002), $b_{1}$ is the coefficient of interest, and is expected to be positive, the past earnings coefficient $b_{2}$ is expected to be negative, the current earnings coefficient $b_{3}$ is expected to be positive, and the future returns coefficient $b_{4}$ is expected to be negative.

The inclusion of past, current and future earnings in equation (5) allows for a more general autoregressive expectation model for earnings (Lundholm and Myers, 2002). $E_{i t}$ and 
$E_{i t-1}$ are used as proxy for unexpected current earnings, therefore the past earnings coefficient $b_{2}$ is expected to be negative and the current earnings coefficient $b_{3}$ is expected to be positive to reflect the mean-reverting nature of earnings (Lundholm and Myers, 2002). That is, it is assumed that earnings follow a mean-reverting process, which is consistent with a negative serial correlation in earnings. When both coefficients $\left(b_{2}\right.$ and $\left.b_{3}\right)$ have similar magnitude but they have opposite signs, the current earnings follow a random walk process.

The coefficient of interest, $b_{1}$, is expected to be positive as this implies that future earnings is embedded in current returns (Collins et al., 1994; Lundholm and Myers, 2002). Both $E 3_{i t}$ and $R 3_{i t}$ are used to represent changes in expected future earnings (Lundholm and Myers, 2002). In particular, $E 3_{i t}$ is used as a proxy for expected future earnings. However, $E 3_{i t}$ is realized future earnings that has expected and unexpected components. The latter component implies that this proxy suffers from measurement error, i.e. errors-in-variable problem associated with the use of realized future earnings, $E 3_{i t}$, instead of the unobserved future earnings. $R 3_{i t}$ is added to control for this measurement error, assuming that future returns have correlation with unexpected future earnings changes. Lundholm and Myers (2002) demonstrate that future returns $\left(R 3_{i t}\right)$ should be negatively associated with current returns in a regression model that includes future earnings. The logic behind this is explained in Collins et al., (1994). First note that the higher the correlation between the proxy $\left(R 3_{i t}\right)$ and measurement errors in $E 3_{i t}$, the greater the reduction in the errors-in-variable problem. Consequently, the sign on the measurement-error proxy $\left(R 3_{i t}\right)$ should be opposite to the sign of the partial correlation between this proxy $\left(R 3_{i t}\right)$ and the measurement errors in $E 3_{i t}$. Since $R 3_{i t}$ is expected to be positively correlated with measurement errors in $E 3_{i t}$, a negative sign on $R 3_{i t}$ would subtract this measurement error from 
the realized future earnings, $E 3_{i t}{ }^{7}$. This is equivalent to only including the unexpected component of future earnings in the model.

\section{Data and Descriptive Statistics}

Our sample consists of listed banks in 12 countries with dual banking systems, where both Islamic banks and conventional banks operate ${ }^{8}$. We collect financial data from Datastream and macroeconomic data from the World Bank and central banks websites. The sample covers 2,210 yearly observations for 170 banks across 12 countries over the period 2005-2017. Table AI in the appendix displays the variables used in this study.

Based on the information collected from Datastream and the webpages of each banks we classify banks into two categories: $I B$ (Islamic Bank) and $C B$ (Conventional Bank). Panel A of Table AII in appendix presents the sample distribution by country and bank type. Our sample includes 44 Islamic banks and 126 conventional banks. Bangladesh has the highest number of Islamic banks (8), followed by UAE (7) and Bahrain (6). Indonesia and Bangladesh have the highest number of Conventional banks with 35 and 25 banks, respectively.

Panel B of Table AII illustrates ownership structure and cross-listing status of banks in our sample. We classify banks into three categories: domestic privately-owned banks (Domestic), state-owned banks (State), and foreign-owned banks (Foreign). The proportion of Islamic banks with foreign-owners is higher than that for conventional banks. About 68\% (74\%) of Islamic (Conventional) banks are domestic privately owned banks. Foreigners own 30\% of

\footnotetext{
7 Collins et al. (1994) explain this positive correlation as follow. The measurement error is generated by unanticipated events occurring in future periods. These unanticipated events could affect future earnings, and consequently will be reflected in future returns. If these unanticipated events increase (decrease) future cash flows, then future earnings and future returns will be higher (lower). Therefore, future returns should be positively correlated to unanticipated future earnings (which acts as measurement errors in future earnings).

${ }^{8}$ We have 12 countries in our sample: Bahrain, Bangladesh, Egypt, Indonesia, Jordan, Kuwait, Malaysia, Pakistan, Qatar, Saudi Arabia, Turkey, and UAE.
} 
Islamic banks and $17 \%$ of conventional banks. Sixteen percent of Islamic banks and $23 \%$ of conventional banks are cross-listed. Finally, Table AIII in the appendix shows macroeconomic indicators of the countries in our sample. The average GDP_growth over the study period ranges between 3.17 and $10.38 \%$. The former belongs to Kuwait and the latter is the growth rate of Qatar. Bahrain has the minimum average interest_rate, which is equal to $1.30 \%$, whereas Turkey has the highest interest_rate in our sample.

Table I presents descriptive statistics of our variables. It also shows the p-value for mean equality test between Islamic banks and conventional banks. The summary statistics of our informativeness proxies reveal that Islamic banks have relatively lower levels of informativeness relative to conventional banks. For instance, the mean value of firm specific return variation, e.g., Non_SYNCHRO, is 0.75 for Islamic banks and 0.98 for conventional banks. The difference in the mean of the two groups of banks is statistically significant at the $1 \%$ level. Note that a lower firm specific return variation (Non_SYNCHRO) implies a lower level of price informativeness. Moreover, the mean value of the illiquidity ratio (illiq) is 1.28 and 14.73 for Islamic and conventional banks, respectively. Again, this difference is significant at the $1 \%$ level, confirming that Islamic banks have a lower level of price informativeness. The mean equality test results show that current returns $\left(R_{i t}\right)$ and future returns $\left(R 3_{i t}\right)$ of Islamic banks are not significantly different from current and future returns of conventional banks. However, the mean equality test results for current earnings $\left(E_{t}\right)$ and lagged earnings $\left(E_{t-1}\right)$ are statistically significant at the $1 \%$ level, with both measures being lower for Islamic banks.

\section{[Insert Table I here]}

The mean equality tests on bank characteristics demonstrate that leverage and cost inefficiency of Islamic banks are not significantly different from those of conventional banks. 
However, Islamic banks are, on average, larger and have higher asset growth and nonperforming loans compared to conventional banks.

Table AIV in the appendix presents the pairwise correlation matrix between the variables used in our analysis. It does not show any major collinearity among our explanatory variables. To exclude possible outliers, all variables used in the analysis are winsorized at the $1^{\text {st }}$ and $99^{\text {th }}$ percentiles. All regression specifications include dummies for year and country fixed effects that are not reported in the Tables. Moreover, all variables are expressed in US dollars to control for any effects of exchange rates.

\section{Empirical Results}

\subsection{Stock Return Non-Synchronicity of Islamic and Conventional Banks}

In this sub-section we examine whether stock prices of Islamic banks are less informative than those of their conventional counterparts using firm specific return variation (Non_SYNCHRO) measure. We estimate Equation (2) using random effects technique ${ }^{9}$. Table II presents the results.

[Insert Table II here]

In the first column of Table II, we regress the non-synchronicity measure (Non_SYNCHRO) on Islamic banks' dummy, a set of bank characteristics, country characteristics, and year and country fixed effects. The coefficient associated with the Islamic banks' dummy is negative and statistically significant at the $1 \%$ level. This finding suggests that Islamic banks have, on average, lower price informativeness compared to conventional banks.

As shown in Table AII, banks in our sample have different ownership structures, where banks are owned by domestic private sectors, Governments or foreigners. We argue that

\footnotetext{
${ }^{9}$ The random effects model allows us to capture all unobservable factors that are not captured by our regressors, but still influence the estimation.
} 
ownership structure affects stock price informativeness. In particular, we expect foreign-owned banks to exhibit higher transparency and consequently higher price informativeness. In the second column of Table II, we augment the regression shown in the first column by adding two dummies representing foreign-owned banks (Foreign_D) and state-owned banks $($ State_D), the domestic privately-owned banks is the base group. As expected, the coefficient of the variable Foreign_D is positive and statistically significant, indicating that foreign owned banks have higher price informativeness. Our main variable of interest, Islamic banks' dummy, continues to be negative and statistically significant. Moreover, the magnitude of its coefficient increases from -0.64 to -0.74 after adding the ownership structure to the regression.

Table AII also shows that some banks in our sample are cross-listed. It is also intuitive to expect that the stock prices of cross-listed banks to be more informative due to the disclosure requirements of several listing exchanges, in particular those located in developed countries. In the third column of Table II, we augment further the regression by adding a dummy variable for cross-listed banks (cross_listed_D). Although the coefficient of the cross-listed dummy is not significant, our main variable of interest, Islamic banks' dummy, continues to be negative and statistically significant.

The economic magnitude is substantial. Holding all other factors constant, the stock price non-synchronicity is, on average, about 0.73 lower for Islamic banks relative to their conventional counterparts, which equals around $74 \%\left(\approx \frac{0.73}{0.98}\right)$ of the average Non_SYNCHRO of conventional banks. We can calculate the economic magnitude based on the ratio of $\left(1-\mathrm{R}^{2}\right) / \mathrm{R}^{2}$ as follows: The average non-synchronicity of conventional and Islamic banks are $2.66(\approx \exp (0.98))$ and $1.28(\approx \exp (0.98-0.73))$, respectively. Therefore, non-synchronicity of Islamic banks is, on average, $48 \%(\approx 1.28 / 2.66)$ of non-synchronicity of conventional banks. This implies that the 
idiosyncratic variation in the stock return, i.e., not explained by market and industry returns that is $\left(1-\mathrm{R}^{2}\right)$, is lower for Islamic banks by about $22 \%$. In other words, stock returns of Islamic banks convey less private information. In sum, the findings of Table II suggest that Islamic banks have, on average, lower level of price informativeness compared to conventional banks.

In terms of bank characteristics, the results show that bank size has a significantly negative association with stock price non-synchronicity, indicating that smaller banks in our sample have higher price informativeness. The stock prices of small banks impound more information about the bank fundamentals. This could be explained by the fact that larger banks are associated with higher information asymmetry, as perceived by market participants, due to the complexity of their operations and organization structure which is in line with the extant literature (e.g., Durnev et al., 2001; Durnev et al., 2003; Piotroski and Roulstone, 2004; Dasgupta et al., 2010). Banks asset growth rate has a significantly positive association with stock price non-synchronicity. Previous studies (Durnev et al., 2003; Chan et al., 2017) support this finding. Inefficiency depicts insignificant relationship with our informativeness proxy. The results on bank risk indicators show that banks with higher Non-performing Loans have higher stock price non-synchronicity, which is in line with the existing literature (e.g., Jin and Myers, 2006; Dasgupta et al., 2010). However, we do not find a significant relationship between Leverage and stock price non-synchronicity. Finally, the results show that GDP per capita growth rate has a significantly negative relationship with stock return non-synchronicity, whereas we find little association between Interest Rate and stock return non-synchronicity.

\subsection{Stock price illiquidity ratio of Islamic and Conventional Banks}

In this sub-section, we examine whether stock prices of Islamic banks are less informative than those of their conventional counterparts using the illiquidity ratio (illiq) that is introduced by 
Amihud (2002). Illiquidity ratio is the annual average of the weekly ratio between the stock return absolute value and the stock trading volume in dollars (multiplied by $10^{6}$ ). It measures the impact of trades on the stock price, which is positively related to the quantity of informed trading of a stock (Kyle, 1985; Fresard, 2012). The higher the illiquidity ratio, the higher the stock price informativeness is, i.e. the stock price is following its fundamental value more closely.

Table III illustrates the results of the estimation of Equation (4) using random effects technique. In the first column of Table III, we regress the illiq measure on the Islamic bank dummy, a set of bank characteristics, country characteristics, and year and country fixed effects. The coefficient associated with the Islamic bank dummy is negative and statistically significant at the $1 \%$ level. This finding suggests that Islamic banks have, on average, lower price informativeness compared to conventional banks. In the second and the third columns of Table III, we add the ownership structure (Foreign_D and State_D) and the cross-listing (cross_listed_D) variables, respectively. Although none of the coefficients associated with the latter variables are significant, our main variable of interest, Islamic banks' dummy, continues to be negatively and statistically significant. Holding all other factors constant, the magnitude of the stock price illiquidity ratio is, on average, 9.37 lower for Islamic banks relative to their conventional counterparts. This value represents around $63 \%$ of the average illiquidity ratio for conventional banks.

\section{[Insert Table III here]}

Overall, the findings reported in Table II and III are consistent and suggest that Islamic banks have, on average, lower price informativeness compared to conventional banks.

\subsection{Current Return- Future Earnings Nexus for Islamic and Conventional Banks}


In this sub-section, we consider the strength of the relationship between current stock returns and future earnings for Islamic vis-a-vis conventional banks, and we use the current return-future earnings regression model proposed by Lundholm and Myers (2002). The coefficient associated with future earnings $\left(E 3_{i t}\right)$ is the coefficient of interest. If this coefficient is positive and significant, then stock price embeds more information about future earnings, i.e., stock price is tracking its fundamental value more closely. If this coefficient is not significant, then stock price incorporates no or little information about future earnings, i.e., stock price deviates from its fundamental value.

In Table IV, we estimate Equation (5) by regressing the current return $\left(R_{i t}\right)$ on future earnings $\left(E 3_{i t}\right)$, lagged earnings $\left(E_{t-1}\right)$, current earnings $\left(E_{t}\right)$, a set of bank characteristics, country characteristics, and year and country fixed effects. We estimate the model by using random effects technique. Column (1) reports the ability of current stock return for Islamic banks $(I B)$ to predict its future earnings. In a similar vein, column (2), presents the informativeness ability for conventional banks $(C B)$. The future earnings $\left(E 3_{i t}\right)$ coefficient $\left(b_{1}\right)$ is positive as expected, however, it is only marginally significant (at 10\% level) for Islamic banks. In contrast, the future earnings $\left(E 3_{i t}\right)$ coefficient $\left(b_{1}\right)$ is positive and highly significant (at $1 \%$ level) for conventional banks. This implies that current returns $\left(R_{i t}\right)$ of conventional banks have higher future earnings $\left(E 3_{i t}\right)$ prediction ability in comparison with Islamic banks. Moreover, for conventional banks, the coefficient of current earnings (future returns), $b_{3}$ and $b_{4}$, respectively, is significantly positive (negative), which is in line with the literature.

\section{[Insert Table IV here]}

Furthermore, column (1) shows that Islamic banks current return $\left(R_{i t}\right)$ is significantly positively associated with asset growth, and has a significantly negative correlation with the 
cross listing dummy (cross_listed_D). In column (2) we find that current return $\left(R_{i t}\right)$ of conventional banks has a significantly negative relationship with government ownership (State_D). The results also show that current return $\left(R_{i t}\right)$ of both Islamic banks and conventional banks is negatively correlated with interest rate. Overall, the findings in this sub-section are consistent with the results reported in Tables II and III and suggest that Islamic banks generally have a lower price informativeness in comparison with conventional banks.

\subsection{Robustness checks}

We conduct two additional robustness checks to ensure our findings are robust under different environment and jurisdictions. Specifically, we repeat our analysis for different subsamples constructed based on the time period (crisis and non-crisis period) and countries $\left(\mathrm{GCC}^{10}\right.$-member countries and Non GCC-member countries).

Since our sample period covers the financial crisis (2008-2009), our results could be affected by the crisis. To explore this, we repeat our analysis for two subsamples constructed based on the time period: crisis period (i.e. 2008-2009), and non-crisis period (all years excluding 2008-2009) ${ }^{11}$. The results for non-crisis period are similar to the main findings of the paper. The only exception occurs when the dependent variable is the Amihud (2002) illiquidity ratio (illiq) where the Islamic banks' dummy remains negative, but it becomes insignificant. However, the results for crisis period are mixed as they depend on how price informativeness is measured, e.g., Islamic banks have lower stock return non-synchronicity (Non_SYNCHRO ), but higher future earnings $\left(\mathrm{E} 3_{\mathrm{it}}\right)$ prediction ability in comparison with conventional banks.

\footnotetext{
${ }^{10}$ GCC refers to the Gulf Cooperation Council.

11 The results are not reported in the paper, but they are available upon request from the authors.
} 
We also repeat our analysis for two subsamples based on countries: GCC member countries and Non-GCC countries. This is important as Islamic banking practices are different across countries and regions. Moreover, several studies focus on the GCC countries, which represents about the third of total global Islamic financial assets (Srairi, 2010; Miah and Uddin, 2017). We investigate whether the findings are different for these two groups of countries ${ }^{12}$.

The results for the GCC countries are qualitatively similar to those reported for the whole sample. The only exception occurs when the dependent variable is the Amihud (2002) illiquidity ratio (illiq) where the Islamic banks' dummy remains negative, but it becomes insignificant. However, the results for non-GCC countries are different from those for GCC member-countries. For this group of countries, Islamic banks have lower stock return non-synchronicity (Non_SYNCHRO), but higher future earnings (E3 ${ }_{\text {it }}$ ) prediction ability in comparison with conventional banks. We conclude that our main findings are valid for the GCC member countries and during the non-crisis period.

\subsection{Discussion of Results}

This study finds that stock prices of Islamic banks are less informative compared to conventional banks. Specifically, Islamic banks exhibit lower stock return non-synchronicity, lower illiquidity ratio, and their stock price incorporates no or little information about future earnings. ${ }^{13}$ This implies that informed trading activity based on private information is lower for Islamic banks, i.e., stock returns of Islamic banks convey less firm-specific information and have lower

\footnotetext{
${ }^{12}$ The results are not reported in the paper, but they are available upon request from the authors.

13 As shown in Table AII, our sample includes a large number of banks operating in two countries, namely Bangladesh (8 Islamic Banks and 25 Conventional Banks) and Indonesia (1 Islamic bank and 35 conventional banks). It is plausible to think that our findings might be influenced by these two countries. To examine this possibility, we re-estimate our models after excluding all Islamic banks and conventional banks operating in both countries: Bangladesh and Indonesia. The results, not reported here and are available upon request from the authors, are similar to those obtained from the main analysis. The only exception occurs when the dependent variable is the Amihud (2002) illiquidity ratio (illiq) where the Islamic bank dummy remains negative, but it becomes not significant. We conclude that our main findings are not materially affected by banks from these two countries.
} 
predictive ability about future earnings. Consequently, stock prices of Islamic banks might not be fully driven by banks' fundamentals. We argue that this is due to the complexity and opacity of Islamic banking compared to conventional banking. ${ }^{14}$ The complexity of Islamic banking stems from the factors related to its business model (Mollah and Zaman, 2015). For instance, compliance of their operation with Sharia mandates establishment of Sharia Supervisory Board, which could affect performance, risk-taking and governance of Islamic banks (Mollah and Zaman, 2015).

The opacity of Islamic banking stems from factors related to the level of disclosure and reporting as well as the nature of Islamic financial products. For example, Abdullah et al. (2015) find that financial disclosure of Islamic banks in the Southeast Asia and GCC regions is relatively low. This implies that asymmetric information problems between insiders (bank managers) and outside investors might be more severe for Islamic banks. Islamic bank opacity could also be linked to the complexity of Islamic financial products such as Mudarabah investment account where depositors are investment account holders (IAHs). For example, AlShattarat and Atmeh (2016) argue that Mudarabah contract is associated with a major corporate governance problem where the depositors are exposed to the risk of equity-holders, but they have no similar rights. Mudarabah contract is also associated with the problem of profit determination and allocation among involved parties.

Since deposit amounts and their returns are not guaranteed in a Mudarabah contract, Islamic banks heavily use reserves to smooth the payout to IAHs, and this policy adversely

\footnotetext{
${ }^{14}$ Jones et al. (2012) defines opacity as the uncertainty in appraising the fundamental value of a firm accurately. Several sources could contribute to opaqueness, including poor disclosure quality, complexity of a business model and the characters of the underlying assets.
} 
affects transparency of their financial statements (AlShattarat and Atmeh, 2016). ${ }^{15}$ In particular, the classification of IAH and its related reserves in the financial statements are still under debate. The Accounting and Auditing Organization for Islamic Financial Institutions (AAOIFI) established a new category for IAHs separate from the traditional categories, i.e., assets, liabilities and stockholders' equity. Many scholars (e.g., Atmeh and Ramadan, 2012; AlShattarat and Atmeh, 2016) argue that creating a separate category for IAHs, without reclassifying the assets which are attributable to IAHs, affects transparency of financial statements, because this strategy contradicts full disclosure policy. This is a simple illustration of the higher level of opacity in the intermediation process of Islamic banks compared to conventional banks. Indeed, the opacity level varies even among conventional banks themselves. For example, Blau et al. (2017) find that opacity is positively associated with price delay. In particular, they find that more opaque conventional banks have longer delay than less opaque conventional banks. They use both market-based measures and accounting-based measures to represent informational opacity.

In sum, compared to conventional banks, the information about the risks of Islamic banks' assets are relatively opaque. The opacity of Islamic banks, e.g., lack of information about assets' risks, adversely affect the ability of outsiders (such as analysts, investors and rating agencies) to accurately assess the inherent risks of Islamic banks. The complexity and opacity in the intermediation process of Islamic banks create uncertainty that makes it difficult for outsiders to understand and assess the inherent risks of Islamic banks. Consequently, Islamic banks will have less informed stock prices because outsiders will have difficulty to estimate their true value.

\footnotetext{
${ }^{15}$ Islamic banks can use two types of reserves: investment risk reserve and profit equalization reserve (AlShattarat and Atmeh, 2016). The latter is used to uphold level of returns to IAHs, whereas the former is used by Islamic banks to guarantee the principal values of deposits to IAHs. These reserves are legalized by Islamic Jurists using donation (Tabarru) contracts.
} 
Thus, the complexity and opacity of Islamic banks adversely affect their stock price informativeness. As a result, market forces may not be an effective tool in disciplining the management of Islamic banks, because opacity limits informed arbitrage (Jones et al., 2012). Our finding has important implications for regulators. Islamic banks require more regulatory scrutiny, e.g., regulators might consider introducing mandatory disclosure requirements designed to increase the transparency to outsiders about the risks associated with the intermediation process.

\section{Concluding Remarks}

This paper investigates the informativeness of stock prices of Islamic banks vis-à-vis conventional banks. We use three price informativeness proxies in our analysis: stock returns non-synchronicity, stocks illiquidity ratio and future earnings prediction ability of current returns.

We study a sample of 2,210 observations for 170 banks across 12 countries over the 2005-2017 timespan. We show that Islamic banks have lower stock return non-synchronicity, lower illiquidity ratio, and their current returns have lower future earnings prediction ability in comparison with conventional banks. The findings hold for the GCC-member countries and during the non-crisis period. Our results suggest that in such countries stock prices of Islamic banks have a lower level of informativeness compared to conventional banks. This could be because Islamic banks use more complex financial products and have lower degree of transparency mandated by their financial paradigm. As shown in the financial crises, there are a lot of information asymmetry problems in the banking industry and banks' information disclosure should be improved. Our results suggest that Islamic banks require even closer supervision, because market discipline might be less effective for them relative to conventional banks. The finding has important implications for policymakers and investors. 


\section{Table I. Descriptive statistics}

This table illustrates the summary statistics of the variables used in the regression specifications for Islamic banks and conventional banks. The last column in the table reports the p-value for mean equality test between the two banks types. The sample covers 2,210 observations for 170 banks across 12 countries over the period 2005-2017. The informativeness measures are included in Informativeness proxies: Non_SYNCHRO is the measure of stock return non-synchronicity, and illiq is the mean weekly ratio of a stock's absolute return to the dollar volume. Return measures are included in Return proxies: $R_{t}$ is Current return, and $R 3_{t}$ is Future return. Earnings measures are included in Earnings proxies: $E 3_{t}$ is Future earnings, $E_{t}$ is current earnings, and $E_{t-1}$ is lagged earnings. Bank specific factors are included in Bank characteristics: logarithm of total assets (size), growth rate of total assets (asset_growth), ratio of noninterest expense to net income (inefficiency), financial leverage (leverage) and the ratio of non-performing loans to net loans (nploans).

\begin{tabular}{|c|c|c|c|c|c|c|c|c|c|c|c|}
\hline \multirow[b]{2}{*}{ Variables } & \multirow[b]{2}{*}{$\mathrm{N}$} & \multicolumn{3}{|c|}{ Islamic banks } & \multicolumn{7}{|c|}{ Conventional banks } \\
\hline & & Mean & $\mathrm{SD}$ & Min & $\operatorname{Max}$ & $\mathrm{N}$ & Mean & SD & Min & Max & $\begin{array}{c}* \text { P-value } \\
\text { of t-test }\end{array}$ \\
\hline \multicolumn{12}{|c|}{ Informativeness proxies } \\
\hline Non_SYNCHRO & 484 & 0.75 & 1.48 & -1.93 & 5.47 & 1199 & 0.98 & 1.73 & -2.11 & 5.47 & 0.01 \\
\hline illiq & 453 & 1.28 & 9.13 & 0 & 147.42 & 1244 & 14.73 & 68.4 & 0 & 479.29 & 0.00 \\
\hline \multicolumn{12}{|l|}{ Return proxies } \\
\hline$R_{t}$ & 447 & 0.02 & 0.44 & -1.35 & 1.25 & 1,221 & 0.04 & 0.44 & -1.35 & 1.25 & 0.54 \\
\hline$R 3_{t}$ & 365 & 0.02 & 0.67 & -1.8 & 2.08 & 1,006 & 0.06 & 0.65 & -1.8 & 2.08 & 0.39 \\
\hline \multicolumn{12}{|l|}{ Earnings proxies } \\
\hline$E 3_{t}$ & 383 & 0.2 & 0.31 & -0.8 & 1.29 & 1,146 & 0.23 & 0.29 & -0.8 & 1.29 & 0.10 \\
\hline$E_{t}$ & 373 & 0.06 & 0.14 & -0.53 & 0.39 & 1,087 & 0.09 & 0.1 & -0.53 & 0.39 & 0.00 \\
\hline$E_{t-1}$ & 344 & 0.06 & 0.14 & -0.53 & 0.35 & 1,030 & 0.09 & 0.1 & -0.53 & 0.35 & 0.00 \\
\hline \multicolumn{12}{|c|}{ Bank characteristics } \\
\hline size & 451 & 15.34 & 1.25 & 11.03 & 18.33 & 1,296 & 15.11 & 1.76 & 11.03 & 18.43 & 0.01 \\
\hline asset_growth & 409 & 0.2 & 0.23 & -0.29 & 1.2 & 1,178 & 0.15 & 0.2 & -0.29 & 1.2 & 0.00 \\
\hline inefficiency & 381 & 2.94 & 6.99 & -4.75 & 54.87 & 1,084 & 3.43 & 7.43 & -4.75 & 54.87 & 0.26 \\
\hline leverage & 451 & 0.14 & 0.17 & 0 & 0.77 & 1,296 & 0.13 & 0.13 & 0 & 0.77 & 0.34 \\
\hline nploans & 302 & 0.08 & 0.1 & 0 & 0.64 & 950 & 0.06 & 0.08 & 0 & 0.64 & 0.01 \\
\hline
\end{tabular}

*The p-value of mean equality test between Islamic banks and conventional banks. The difference between the means of the two groups is statistically significant at the $1 \%(5 \%)$ level if the corresponding p-value is lower than $1 \%(5 \%)$. Table AI provides the definition of the variables. 


\section{Table II. Banks' stock return non-synchronicity and price informativeness}

This table illustrates the estimation results of Equation (2) using random effects technique, in which we regress stock return nonsynchronicity (Non_SYNCHRO $i t$ ), obtained from Equation (1), on a set of control variables. We consider conventional banks as the base group. In the first column, we regress the informativeness measure Non_SYNCHRO $i t$ on Islamic banks' dummy Islamic_D, the set of bank and country characteristics including size, asset_growth, inefficiency, leverage, nploans, GDB_growth, and interest_rate. In the second column, we add to the regression two dummies representing bank ownership structure: state-owned banks state_D, and foreign-owned banks foreign_D. In the third column, we add to the regression a dummy for cross-listed banks cross_Listed. Country and year fixed effects are incorporated in the regressions; however, their coefficients are not reported.

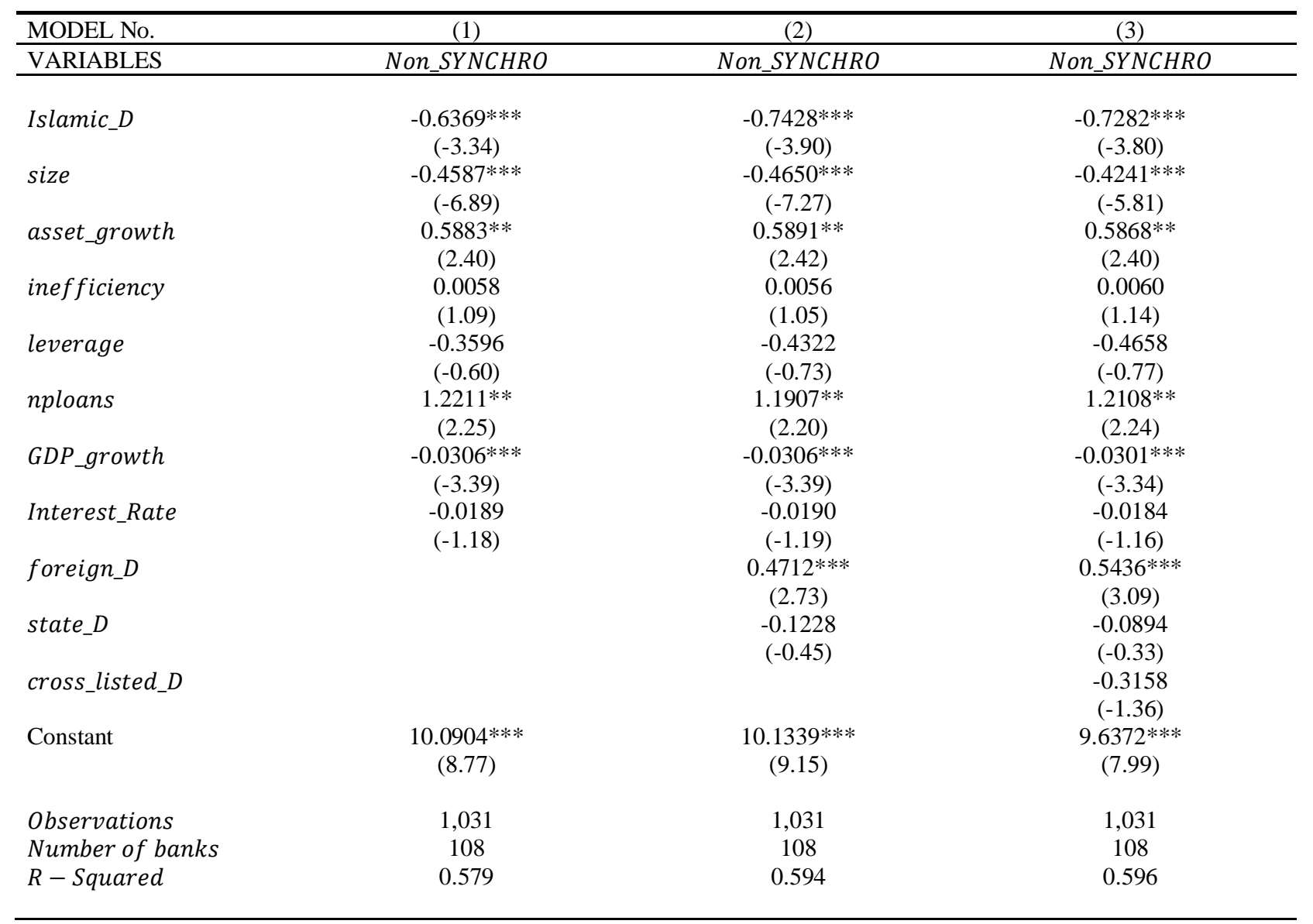

Robust $\mathrm{z}$-statistics are presented in parentheses. $* \mathrm{p}<0.1, * * \mathrm{p}<0.05, * * * \mathrm{p}<0.01$. 


\section{Table III. Banks' illiquidity ratio and stock price informativeness}

This table illustrates the estimation results of Equation (4) using random effects technique, in which we regress illiquidity measure (illiq), obtained from Equation (3), on a vector of control variables. We consider conventional banks as the base group. In the first column, we regress the informativeness measure illiq on Islamic banks' dummy Islamic_D, the set of bank and country characteristics including size, asset_growth, inefficiency, leverage, nploans, GDB_growth, and interest_rate. In the second column, we add to the regression two dummies representing bank ownership structure: state-owned banks state_D, and foreign-owned banks foreign_D. In the third column, we add to the regression a dummy for cross-listed banks cross_Listed. Country and year fixed effects are incorporated in the regressions; however, their coefficients are not reported.

\begin{tabular}{|c|c|c|c|}
\hline MODEL No. & $(1)$ & (2) & (3) \\
\hline VARIABLES & illiq & illiq & illiq \\
\hline Islamic_D & $\begin{array}{c}-8.2131^{*} \\
(-1.87)\end{array}$ & $\begin{array}{c}-10.1362 * * \\
(-2.21)\end{array}$ & $\begin{array}{c}-9.3744 * * \\
(-2.02)\end{array}$ \\
\hline size & $\begin{array}{c}-5.0153 \\
(-1.20)\end{array}$ & $\begin{array}{c}-4.9138 \\
(-1.18)\end{array}$ & $\begin{array}{c}-2.9197 \\
(-0.62)\end{array}$ \\
\hline asset_growth & $\begin{array}{l}1.0902 \\
(0.04)\end{array}$ & $\begin{array}{c}0.9814 \\
(0.03)\end{array}$ & $\begin{array}{c}0.8476 \\
(0.03)\end{array}$ \\
\hline inefficiency & $\begin{array}{c}0.3087 \\
(0.82)\end{array}$ & $\begin{array}{c}0.3078 \\
(0.81)\end{array}$ & $\begin{array}{c}0.3214 \\
(0.86)\end{array}$ \\
\hline leverage & $\begin{array}{c}20.3233 \\
(0.85)\end{array}$ & $\begin{array}{c}19.6337 \\
(0.82)\end{array}$ & $\begin{array}{c}18.4841 \\
(0.80)\end{array}$ \\
\hline nploans & $\begin{array}{c}18.8346 \\
(0.79)\end{array}$ & $\begin{array}{c}19.1457 \\
(0.80)\end{array}$ & $\begin{array}{c}20.1947 \\
(0.85)\end{array}$ \\
\hline GDP_growth & $\begin{array}{c}0.3590 \\
(1.16)\end{array}$ & $\begin{array}{c}0.3629 \\
(1.17)\end{array}$ & $\begin{array}{c}0.3905 \\
(1.24)\end{array}$ \\
\hline interest_rate & $\begin{array}{l}1.2880 \\
(1.28)\end{array}$ & $\begin{array}{l}1.2778 \\
(1.27)\end{array}$ & $\begin{array}{l}1.3096 \\
(1.28)\end{array}$ \\
\hline foreign_D & & $\begin{array}{c}8.8367 \\
(1.07)\end{array}$ & $\begin{array}{c}12.7327 \\
(1.53)\end{array}$ \\
\hline state_D & & $\begin{array}{c}-3.4721 \\
(-0.39)\end{array}$ & $\begin{array}{c}-1.7344 \\
(-0.19)\end{array}$ \\
\hline cross_listed_D & & & $\begin{array}{c}-14.2105 \\
(-0.89)\end{array}$ \\
\hline Constant & $\begin{array}{c}79.4659 \\
(1.08)\end{array}$ & $\begin{array}{c}76.3998 \\
(1.05)\end{array}$ & $\begin{array}{c}51.2691 \\
(0.64)\end{array}$ \\
\hline $\begin{array}{l}\text { Observations } \\
\text { Number of banks } \\
R-\text { Squared }\end{array}$ & $\begin{array}{c}1,050 \\
113 \\
0.180\end{array}$ & $\begin{array}{c}1,050 \\
113 \\
0.181\end{array}$ & $\begin{array}{c}1,050 \\
113 \\
0.183\end{array}$ \\
\hline
\end{tabular}

Robust z-statistics are presented in parentheses. * $\mathrm{p}<0.1, * * \mathrm{p}<0.05, * * * \mathrm{p}<0.01$. 


\section{Table IV. Banks' future earnings level and stock price informativeness}

This table presents the estimations of Equation (5) using random effects technique. The dependent variable in column (1) is the current return level of Islamic banks $\left(R_{t}\right.$ of $\left.I B\right)$, and in column (2) the current return level of conventional banks $\left(R_{t}\right.$ of $\left.C B\right)$. We regress each bank type current return level at year $\mathrm{t}\left(R_{i t}\right)$ on the following independent variables: $E 3_{i t}$ is the future earnings calculated as the sum of earnings for the year $\mathrm{t}+1, \mathrm{t}+2, \mathrm{t}+3$ and scaled by equity market value at the beginning of year $t, E_{i t-1}$ is earnings of year $t-1$ scaled by equity market value at the beginning of year $t-1, E_{i t}$ is the current earnings in year $t$ scaled by equity market value at the beginning of year $t, R 3_{i t}$ is the future returns over the three-year period that start after three months from the current year end. We also use a vector of bank and country characteristics including size, asset_growth, inefficiency, leverage, nploans, GDB_growth, and interest_rate, two dummies representing bank ownership structure: state-owned banks state_D, and foreign-owned banks foreign_D, and a dummy for cross-listed banks cross_Listed. Country and year fixed effects are incorporated in the regressions; however, their coefficients are not reported.

\begin{tabular}{|c|c|c|}
\hline MODEL No. & $(1)$ & $(2)$ \\
\hline VARIABLES & $R_{t}$ of $I B$ & $R_{t}$ of $C B$ \\
\hline$E 3_{w}$ & $\begin{array}{c}0.4139 * \\
(1.92)\end{array}$ & $\begin{array}{c}0.4169 * * * \\
(3.71)\end{array}$ \\
\hline$E_{w-1}$ & $\begin{array}{c}-0.1555 \\
(-0.78)\end{array}$ & $\begin{array}{c}-0.4749 \\
(-1.56)\end{array}$ \\
\hline$E_{w}$ & $\begin{array}{c}0.0627 \\
(0.19)\end{array}$ & $\begin{array}{c}1.3137^{* *} \\
(2.54)\end{array}$ \\
\hline$R 3_{w}$ & $\begin{array}{c}-0.1058 \\
(-1.51)\end{array}$ & $\begin{array}{c}-0.2131 * * * \\
(-4.95)\end{array}$ \\
\hline size & $\begin{array}{c}-0.0087 \\
(-0.40)\end{array}$ & $\begin{array}{c}-0.0086 \\
(-0.53)\end{array}$ \\
\hline asset_growth & $\begin{array}{c}0.5984 * * \\
(2.31)\end{array}$ & $\begin{array}{c}0.1452 \\
(1.27)\end{array}$ \\
\hline inefficiency & $\begin{array}{c}-0.0063 \\
(-1.31)\end{array}$ & $\begin{array}{c}0.0049 * \\
(1.86)\end{array}$ \\
\hline leverage & $\begin{array}{c}-0.2621 \\
(-0.88)\end{array}$ & $\begin{array}{c}-0.3169^{*} \\
(-1.78)\end{array}$ \\
\hline nploans & $\begin{array}{c}-0.4096 \\
(-1.37)\end{array}$ & $\begin{array}{c}-0.1633 \\
(-0.87)\end{array}$ \\
\hline GDP_growth & $\begin{array}{c}-0.0106 \\
(-1.24)\end{array}$ & $\begin{array}{c}-0.0036 \\
(-0.86)\end{array}$ \\
\hline interest_rate & $\begin{array}{c}-0.0701 * * * \\
(-3.49)\end{array}$ & $\begin{array}{c}-0.0555^{* * *} * \\
(-5.83)\end{array}$ \\
\hline foreign_D & $\begin{array}{c}0.0109 \\
(0.09)\end{array}$ & $\begin{array}{c}0.0322 \\
(1.00)\end{array}$ \\
\hline state_D & $\begin{array}{c}-0.0329 \\
(-0.73)\end{array}$ & $\begin{array}{c}-0.0942 * * \\
(-2.23)\end{array}$ \\
\hline cross_listed_D & $\begin{array}{c}-0.2013^{* *} \\
(-2.43)\end{array}$ & $\begin{array}{c}0.0071 \\
(0.18)\end{array}$ \\
\hline Constant & $\begin{array}{c}0.1919 \\
(0.55)\end{array}$ & $\begin{array}{l}0.2037 \\
(0.81)\end{array}$ \\
\hline $\begin{array}{l}\text { Observations } \\
\text { Number of banks } \\
R-\text { Squared }\end{array}$ & $\begin{array}{c}169 \\
28 \\
0.639\end{array}$ & $\begin{array}{c}499 \\
74 \\
0.582\end{array}$ \\
\hline
\end{tabular}

Robust z-statistics are presented in parentheses. * $\mathrm{p}<0.1, * * \mathrm{p}<0.05, * * * \mathrm{p}<0.01$. 


\section{References}

Abdullah, W.A.W., Percy, M., Stewart, J., 2015. Determinants of voluntary corporate governance disclosure: Evidence from Islamic banks in the Southeast Asian and the Gulf cooperation council regions. Journal of Contemporary Accounting \& Economics 11(3), 262279. https://doi.org/10.1016/j.jcae.2015.10.001.

Abedifar, P., Giudici, P., Hashem S. Q., 2017. Heterogeneous market structure and systemic risk: Evidence from dual banking systems. Journal of Financial Stability 33, 96-119. https://doi.org/10.1016/j.jfs.2017.11.002.

Abedifar, P., Hasan, I., Tarazi, A., 2016. Finance-growth nexus and dual-banking systems: relative importance of Islamic banks. Journal of Economic Behavior \& Organization 132, 198-215, special issue on Islamic Finance. https://doi.org/10.1016/j.jebo.2016.03.005.

Abedifar, P., Molyneux, P., Tarazi A., 2013. Risk in Islamic Banking. Review of Finance 17(6), 2035-2096. https://doi.org/10.1093/rof/rfs041.

Alandejani, M., Kutan, A. M., Samargandi, N., 2017. Do Islamic banks fail more than conventional banks? Journal of International Financial Markets Institutions \& Money, 50, 135-155. https://doi.org/10.1016/j.intfin.2017.05.007.

Al-Baluchi, A. E. A., 2006. The Impact of AAOIFI Standards and Other Bank Characteristics on the Level of Voluntary Disclosure in the Annual Reports of Islamic Banks. Ph.D. Thesis, School of Management, University of Surrey.

Al-Jarrah, I., Molyneux, P., 2005. Efficiency in Arabian banking. In: M. Iqbal and R. Wilson (eds), Islamic Perspectives on Wealth Creation. Edinburgh University Press, Edinburgh.

Allen, F. 1993., Strategic management and financial markets. Strategic Management Journal 14, 11-22. https://doi.org/10.1002/smj.4250141004.

Alqahtani, F., Mayes, D. G., Brown, K., 2017. Islamic bank efficiency compared to conventional banks during the global crisis in the GCC region. Journal of International Financial Markets, Institutions \& Money, 51, 58-74. https://doi.org/10.1016/j.intfin.2017.08.010.

AlShattarat, W. K., Atmeh, M. A., 2016. Profit-sharing investment accounts in Islamic banks or mutualization, accounting perspective. Journal of Financial Reporting and Accounting 14(1), 30-48. https://doi.org/10.1108/JFRA-07-2014-0056.

Amihud, Y., 2002. Illiquidity and stock returns: cross-section and time-series effects. Journal of Financial Markets 5(1), 31-56. https://doi.org/10.1016/S1386-4181(01)00024-6.

Assaf, G., Berger, A., Roman, R., Tsionas, M., 2019. Does efficiency help banks survive and thrive during financial crises? Journal of Banking and Finance 106, 445-470. https://doi.org/10.1016/j.jbankfin.2019.07.013.

Athari, S. A., Adaoglu, C. Bektas, E., 2016. Investor protection and dividend policy: The case of Islamic and conventional banks. Emerging Markets Review 27, 100-17. https://doi.org/10.1016/j.ememar.2016.04.001.

Atmeh, M., Ramadan, A., 2012. A critique on accounting for the Mudarabah contract. Journal of Islamic Accounting and Business Research 3(1), 7-19. https://doi.org/10.1108/17590811211216032. 
Aysan, A. F., Disli, M., Ng, A., Ozturk, H., 2016. Is small the new big? Islamic banking for SMEs in Turkey. Economic Modelling 54, 187-194. https://doi.org/10.1016/j.econmod.2015.12.031.

Aysan, A. F., Disli, M. Ozturk, H., 2018. Bank lending channel in a dual banking system: Why are Islamic banks so responsive? The World Economy 41, 674-698. https://doi.org/10.1111/twec.12507.

Baele, L., Farooq, M., Ongena, S., 2014. Of religion and redemption: evidence from default on Islamic loans. Journal of Banking \& Finance 44, 141-159. https://doi.org/10.1016/j.jbankfin.2014.03.005.

Basu, S., 1997. The conservatism principle and the asymmetric timeliness of earnings. Journal of Accounting and Economics 24(1), 3-37. https://doi.org/10.1016/S0165-4101(97)00014-1.

Beck, T., Demirguc-Kunt, A., Levine, R., 2004. Stock markets, banks, and growth: Panel evidence. Journal of Banking and Finance 28(3), 423-442. https://doi.org/10.1016/S03784266(02)00408-9.

Beck, T., Demirguc-Kunt, A., Merrouche, O., 2013. Islamic vs. Conventional Banking: Business Model, Efficiency and Stability. Journal of Banking \& Finance 37(2), 433-447. https://doi.org/10.1016/j.jbankfin.2012.09.016.

Bekaert, G., Wu, G., 2000. Asymmetric volatility and risk in equity markets. Review of Financial Studies 13(1), 1-42. https://doi.org/10.1093/rfs/13.1.1.

Blau, B. M., Brough, T. J., Griffith, T. G., 2017. Bank opacity and the efficiency of stock prices. Journal of Banking and Finance 76, 32-47. https://doi.org/10.1016/j.jbankfin.2016.11.026.

Bonin, J. P., Hasan, I., Wachtel, P., 2005. Bank performance, efficiency and ownership in transition countries. Journal of Banking \& Finance 29(1), 31-53. https://doi.org/10.1016/j.jbankfin.2004.06.015.

Cihak, M., Hesse, H., 2010. Islamic Banks and Financial Stability: An Empirical Analysis. Journal of Financial Services Research 38(2-3), 95-113. https://doi.org/10.1007/s10693010-0089-0.

Chan, K., Fengfei, L., Lin, J-C., Lin, T-C., 2017. What do stock price levels tell us about the firms. Journal of Corporate Finance 46, 34-50. https://doi.org/10.1016/j.jcorpfin.2017.06.013.

Collins, D., Kothari, S., Shanken, J., Sloan, R., 1994. Lack of timeliness and noise as explanations for the low contemporaneous returns-earnings association. Journal of Accounting and Economics 18(3), 289-324. https://doi.org/10.1016/0165-4101(94)90024-8.

Dasgupta, S., Gan, J., Gao, N., 2010. Transparency, price informativeness, and stock return synchronicity: theory and evidence. Journal of Financial and Quantitative Analysis 45(5), 1189-1220. https://doi.org/10.1017/S0022109010000505.

Dow, J., Gorton, G., 1997. Stock market efficiency and economic efficiency: Is there a connection? The Journal of Finance 52(3), 1087-1129. https://doi.org/10.1111/j.15406261.1997.tb02726.x. 
Durnev, A., Morck, R., Yeung, B., 2004. Value enhancing capital budgeting and firm-specific stock return variation. The Journal of Finance 59(1), 65-105. https://doi.org/10.1111/j.1540$\underline{6261.2004 .00627 . x}$.

Durnev, A., Morck, R., Yeung, B., Zarowin, P., 2003. Does greater firm-specific return variation mean more or less informed stock pricing. Journal of Accounting Research 41(5), 797836. https://doi.org/10.1046/j.1475-679X.2003.00124.X.

Durnev, A., Yeung, B., Morck, R., 2001. Does firm-specific information in Stock prices capital allocation? Working paper No. w8093, National Bureau of Economic Research. https://www.nber.org/papers/w8093.pdf.

El-Gamal, M., 2005. Limits and Danger of Sharia Arbitrage. In: S. Nazim Ali, ed. Islamic Finance: Current Legal and Regulatory Issues, 117-132. Cambridge, MA: Islamic finance project, Harvard Law School.

El-Gamal, M., 2008. Incoherence of Contract-Based Islamic Financial Jurisprudence in the Age of Financial Engineering.” Wisconsin International Law Journal 25(4), 605-623.

Farag, H., Mallin, C., Ow-Yong, K., 2018. Corporate governance in Islamic banks: New insights for dual board structure and agency relationships. Journal of International Financial Markets, Institutions \& Money 54, 59-77. https://doi.org/10.1016/j.intfin.2017.08.002.

Federal Reserve Study Group on Disclosure. 2000. Improving Public Disclosure in Banking. Federal Reserve Staff Study No. 173.

Fernandes, N., Ferreira, M. A., 2008. Does international cross-listing improve the information environment? Journal of Financial Economics 88(2), 216-244. https://doi.org/10.1016/j.jfineco.2007.06.002.

Ferreira, D., Ferreira, M. A., Raposo, C. C., 2011. Board structure and price informativeness. Journal of Financial Economics 99(3), 523-545. https://doi.org/10.1016/j.jfineco.2010.10.007.

Francis, B. B., Hasan, I., Song, L., Yeung, B. 2015. What determines bank-specific variations in bank stock returns? Global evidence. Journal of Financial Intermediation 24(3), 312-324. https://doi.org/10.1016/j.jfi.2014.06.002.

Fresard, L., 2012. Cash savings and stock price informativeness. Review of Finance 16(4), 9851012. https://doi.org/10.1093/rof/rfr004.

Gheeraert, L., 2014., Does Islamic finance spur banking sector development? Journal of $\begin{array}{lllll}\text { Economic } \quad \text { Behavior } \quad \& \quad \text { Organization } & 103, & \text { S4-S20. }\end{array}$ https://doi.org/10.1016/j.jebo.2014.02.013.

Gheeraert, L., Weill, L., 2015. Does Islamic banking development favour macroeconomic efficiency? Evidence on the Islamic finance-growth nexus. Economic Modelling 47, 32-39. https://doi.org/10.1016/j.econmod.2015.02.012.

Glosten, L. R., Milgrom, P. R., 1985. Bid, ask and transaction prices in a specialist market with heterogeneously informed traders. Journal of Financial Economics 14(1), 71-100. https://doi.org/10.1016/0304-405X(85)90044-3. 
Godlewski, C. J., Turk-Ariss, R., Weill, L. 2013. Sukuk vs. Conventional bonds: A stock market perspective. Journal of Comparative Economics 41(3), 745-761. https://doi.org/10.1016/j.jce.2013.02.006.

Greenspan, A., 2001. The Financial Safety Net. Remarks to the 37th Annual Conference on Bank Structure and Competition of the Federal Reserve Bank of Chicago, Chicago, IL (May $10)$.

Grira, J., Hassan, M. K., Labidi, C., Soumaré, I., 2019. Equity Pricing in Islamic Banks: International Evidence. Emerging Markets Finance and Trade 55, 613-633. https://doi.org/10.1080/1540496X.2018.1451323.

Grossman, S. J., 1976. On the Efficiency of Competitive Stock Markets Where Trades Have Diverse Information. The Journal of Finance 31(2): 573-585. https://doi.org/10.2307/2326627.

Grossman, S. J., Stiglitz, J. E., 1980. On the impossibility of informationally efficient markets. American Economic Review 70(3), 393-408. https://www.jstor.org/stable/1805228.

Hasan, I., Song, L., Wachtel, P., 2014. Institutional development and stock price synchronicity: Evidence from China. Journal of Comparative Economics 42(1), 92-108. https://doi.org/10.1016/j.jce.2013.07.006.

Jin, L., Myers, S. C., 2006. $R^{2}$ around the world: New theory and new tests. Journal of Financial Economics 79(2), 257-292. https://doi.org/10.1016/j.jfineco.2004.11.003.

Jones, J. S., Lee, W. Y., Yeager, T. J., 2012. Opaque banks, price discovery, and financial instability. Journal of Financial Intermediation 21(3), 383-408. https://doi.org/10.1016/j.jfi.2012.01.004.

Jones, J. S., Lee, W. Y., Yeager, T. J., 2013. Valuation and systemic risk consequences of bank opacity. Journal of Banking \& Finance 37(3), 693-706. https://doi.org/10.1016/j.jbankfin.2012.10.028.

Klein, P-O., and Weill, L., 2016. Why do company issue sukuk? Review of Financial Economics 31, 26-33. https://doi.org/10.1016/j.rfe.2016.05.003.

Kyriakos-Saad, N., Vasquez, M., El Khoury, C., El Murr, A., 2016. Islamic Finance and AntiMoney Laundering and Combating the Financing of Terrorism (AML/CFT). International Monetary Fund WP/16/42.

Kyle, A. S., 1985. Continuous Auctions and Insider Trading. Econometrica 53(6), 1315-1335. https://www.jstor.org/stable/1913210.

Levine, R., 1997. Financial Development and Economic Growth: Views and Agenda. Journal of Economic Literature 35(2), 688-726. https://www.jstor.org/stable/2729790.

Levine, R., Loayza, N., Beck, T., 2000. Financial intermediation and growth: Causality and causes. Journal of Monetary Economics 46(1), 31-77. https://doi.org/10.1016/S03043932(00)00017-9.

Lundholm, R., Myers, L. A., 2002. Bringing the future forward: the effect of disclosure on the returns-earnings relation. Journal of Accounting Research 40(3), 809-839. https://doi.org/10.1111/1475-679X.00072. 
Meyer, L. H., 1999. Market Discipline as a Complement to Bank Supervision and Regulation. Speech before the Conference on Reforming Bank Capital Standards, New York.

Miah, M. D., Uddin, H., 2017. Efficiency and stability: A comparative study between Islamic and conventional banks in GCC countries. Future Business Journal 3(2), 172-185. https://doi.org/10.1016/j.fbj.2017.11.001.

Mollah, S., Zaman, M., 2015. Shari'a supervision, corporate governance and performance: Conventional vs. Islamic banks. Journal of Banking and Finance 58, 418-435. https://doi.org/10.1016/j.jbankfin.2015.04.030.

Morck, R., Yeung, B., Yu, W., 2000. The Information content of stock markets: Why do emerging markets have synchronous stock price movements? Journal of Financial Economics 58(1-2), 215-260. https://doi.org/10.1016/S0304-405X(00)00071-4.

Morgan, D. P., 2002. Rating Banks: Risk and Uncertainty in an Opaque Industry. American Economic Review 92(4), 874-888. https://doi.org/10.1257/00028280260344506.

Piotroski, J., Roulstone, B., 2004. The Influence of analysts, institutional investors, and insiders on the incorporation of market, industry, and firm-specific information into stock prices. The Accounting Review 79(4), 1119-1151. https://doi.org/10.2308/accr.2004.79.4.1119.

Roll, R., 1988. R2. The Journal of Finance 43(3), 541-566. https://doi.org/10.1111/j.15406261.1988.tb04591.x.

Shaban, M., Duygun, M., Anwar, M., Akbar, B., 2014. Diversification and banks willingness to lend to small businesses: Evidence from Islamic and conventional banks in Indonesia. Journal of Economic Behavior \& Organization 103, S39-S55. https://doi.org/10.1016/j.jebo.2014.03.021.

Shleifer, A., Vishny, R.W., 1997. A survey of corporate governance. The Journal of Finance 52(2), 737-783. https://doi.org/10.1111/j.1540-6261.1997.tb04820.x.

Srairi, S. A., 2010. Cost and profit efficiency of conventional and Islamic banks in GCC countries. Journal of Productivity Analysis 34(1), 45-62. https://doi.org/10.1007/s11123009-0161-7.

Srairi, S., 2015. Corporate Governance Disclosure Practices and Performance of Islamic Banks in GCC Countries. Journal of Islamic Finance 4(2), 1-17. https://doi.org/10.12816/0024085.

Subrahmanyam, A., Titman, S., 1999. The going-public decision and the development of financial markets. Journal of Finance 54(3), 1045-1082. https://doi.org/10.1111/0022$\underline{1082.00136 .}$

Sulaiman, M., Majid, N. A., Arifin, N. M., 2015. Corporate Governance of Islamic Financial Institutions in Malaysia. Asian Journal of Business and Accounting 8(1), 65-93.

Sundararajan, V., Errico, L., 2002. Islamic financial institutions and products in the global financial system: key issues in risk management and challenges ahead. IMF Working Paper No. WP/02/192, I.M.F., Washington, DC. 
Thaler, R. H., Tversky, A., Kahneman, D., Schwartz, A., 1997. The effect of myopia and loss aversion on risk taking: An experimental test. The Quarterly Journal of Economics 112(2), 647-661. https://doi.org/10.1162/003355397555226.

Uddin, M. H., Kabir, S. H., Mollah, S. 2017. Corporate earnings uncertainty in Islamic banking system: An analysis and evidence. In: KFUPM Islamic Banking and Finance Research Conference, Saudi Arabia. http://cim.kfupm.edu.sa/ibf2017/papers/1_3.pdf.

Van Wijnbergen, S. J. G., Zaheer, S., 2013. Sukuk Defaults: On Distress Resolution in Islamic Finance. Working paper. TI 13-087 / VI / DSF 57. University of Amsterdam and Tinbergen Institute.

Veldkamp, L., 2006. Information markets and the comovement of asset prices. The Review of Economic Studies 73(3), 823-845. https://doi.org/10.1111/j.1467-937X.2006.00397.x.

Weill, L., 2011. Do Islamic banks have greater market power? Comparative Economic Studies 53(2), 291-306. https://doi.org/10.1057/ces.2011.1.

Wurgler, J., 2000. Financial markets and the allocation of capital. Journal of Financial Economics 58(1-2), 187-214. https://doi.org/10.1016/S0304-405X(00)00070-2. 
Table AI. Variable description

\begin{tabular}{|c|c|}
\hline Variables & Description \\
\hline$I B$ & A dummy variable for Islamic banks. \\
\hline$C B$ & A dummy variable for traditional conventional banks. \\
\hline \multicolumn{2}{|c|}{ Informativeness proxies } \\
\hline Non_SYNCHRO & $\begin{array}{l}\text { Stock return non-synchronicity is computed as Non_SYNCHRO } i=\operatorname{Ln}\left[\left(1-R^{2}\right) / R^{2}\right] \text {, where } R^{2} \\
\text { is from a regression of bank's weekly return on industry and market returns. }\end{array}$ \\
\hline illiq & $\begin{array}{l}\text { Average of the weekly ratio between the stock return absolute value and the stock dollar trading } \\
\left.\text { volume (multiplied by } 10^{6}\right) \text {. }\end{array}$ \\
\hline \multicolumn{2}{|l|}{ Return proxies } \\
\hline$R_{i t}$ & Current return calculated as bank $i$ annual return for year $t$. \\
\hline$R 3_{i t}$ & $\begin{array}{l}\text { Future return calculated as bank } i \text { buy and hold return over the three-year period following the } \\
\text { year } t \text {. }\end{array}$ \\
\hline \multicolumn{2}{|l|}{ Earnings proxies } \\
\hline$E 3_{i t}$ & $\begin{array}{l}\text { Future earnings calculated as the sum of earnings for the year } t+1, t+2, t+3 \text {, scaled by equity } \\
\text { market value at the beginning of year } t \text {. }\end{array}$ \\
\hline$E_{i t}$ & $\begin{array}{l}\text { Current earnings calculated as earnings for year } t \text {, scaled by equity market value at the beginning } \\
\text { of year } t \text {. }\end{array}$ \\
\hline$E_{i t-1}$ & $\begin{array}{l}\text { Lagged earnings calculated as earnings for year } t-1 \text {, scaled by equity market value at the } \\
\text { beginning of year } t-1 \text {. }\end{array}$ \\
\hline Variables & Description \\
\hline \multicolumn{2}{|c|}{ Bank characteristics } \\
\hline size & Logarithm of total asset \\
\hline asset_growth & (Total assets at $\mathrm{t}$ minus Total assets at $\mathrm{t}-1$ ) / Total assets at $\mathrm{t}-1$. \\
\hline inefficiency & Noninterest Expense / Net Income \\
\hline leverage & (Long term debt + Short term debt \& Current portion) / total assets. \\
\hline nploans & Non-Performing Loans / Net Loans \\
\hline
\end{tabular}


Table AII. Sample distribution

Panel A. Number of Islamic and conventional banks across 12 countries over 2005-2017 timespan.

\begin{tabular}{|c|c|c|c|c|}
\hline \multirow[b]{2}{*}{ Country } & \multicolumn{2}{|c|}{ Islamic bank } & \multicolumn{2}{|c|}{ Conventional bank } \\
\hline & Banks & Observations & Banks & Observations \\
\hline Bahrain & 6 & 78 & 3 & 39 \\
\hline Bangladesh & 8 & 104 & 25 & 325 \\
\hline Egypt & 3 & 39 & 6 & 78 \\
\hline Indonesia & 1 & 13 & 35 & 455 \\
\hline Jordan & 1 & 13 & 11 & 143 \\
\hline Kuwait & 4 & 52 & 5 & 65 \\
\hline Malaysia & 1 & 13 & 0 & 0 \\
\hline Pakistan & 4 & 52 & 11 & 143 \\
\hline Qatar & 3 & 39 & 4 & 52 \\
\hline Saudi Arabia & 4 & 52 & 0 & 0 \\
\hline Turkey & 2 & 26 & 15 & 195 \\
\hline UAE & 7 & 91 & 11 & 143 \\
\hline Total & 44 & 572 & 126 & 1,638 \\
\hline
\end{tabular}

Panel B. Ownership structure and cross-listing status of banks

\begin{tabular}{lcccc}
\hline & \multicolumn{2}{c}{ Islamic bank } & \multicolumn{2}{c}{ Conventional bank } \\
\hline Country & Banks & Observations & Banks & Observations \\
\hline State-owned banks & 1 & & 12 & 156 \\
Foreign-owned banks & 13 & 169 & 21 & 273 \\
Domestic-owned banks & 30 & 390 & 93 & 1,209 \\
Total & 44 & 572 & & 1,638 \\
& & & 29 & 377 \\
\hline Cross-listed banks & 7 & 91 & & \\
\hline
\end{tabular}




\section{Table AIII. Macroeconomic indicators across countries}

This panel shows the mean value of macroeconomic indicators across 12 countries, over the 2005-2017 period.

\begin{tabular}{lll}
\hline Country & GDP_Per_Capita_Growth $(\%)$ & Domestic_Interest_Rate $(\%)$ \\
\hline Bahrain & 4.62 & 1.30 \\
Bangladesh & 6.36 & 5.00 \\
Egypt & 4.50 & 10.63 \\
Indonesia & 5.56 & 7.40 \\
Jordan & 4.38 & 6.33 \\
Kuwait & 3.17 & 2.12 \\
Malaysia & 4.98 & 3.04 \\
Pakistan & 4.31 & 9.88 \\
Qatar & 10.38 & 4.94 \\
Saudi Arabia & 3.59 & 2.34 \\
Turkey & 5.82 & 12.18 \\
UAE & 3.55 & 2.55 \\
\hline
\end{tabular}




\section{Table AIV. Correlation matrix}

This table presents the pairwise correlation between the variables used in our analysis.

\begin{tabular}{|c|c|c|c|c|c|c|c|c|c|c|c|c|c|c|c|}
\hline & & (1) & (2) & (3) & (4) & (5) & (6) & (7) & (8) & (9) & (10) & (11) & (12) & (13) & (14) \\
\hline Non_SYNCHRO & (1) & 1 & & & & & & & & & & & & & \\
\hline illiq & (2) & $0.2817^{*}$ & 1 & & & & & & & & & & & & \\
\hline$R_{t}$ & (3) & $0.1812^{*}$ & 0.0096 & 1 & & & & & & & & & & & \\
\hline$R 3_{t}$ & (4) & 0.0009 & 0.0058 & -0.0906 & 1 & & & & & & & & & & \\
\hline$E 3_{t}$ & (5) & $-0.1193 *$ & $-0.1275^{*}$ & $0.2400^{*}$ & $0.3947 *$ & 1 & & & & & & & & & \\
\hline$E_{t}$ & (6) & -0.0976 & -0.0703 & $0.3306^{*}$ & $0.1534 *$ & $0.5115^{*}$ & 1 & & & & & & & & \\
\hline$E_{t-1}$ & (7) & $-0.1517^{*}$ & -0.0816 & $0.1140 *$ & 0.0756 & $0.2817 *$ & $0.5681^{*}$ & 1 & & & & & & & \\
\hline size & (8) & $-0.3244 *$ & $-0.1743^{*}$ & 0.0087 & 0.0189 & $0.1307 *$ & $0.1852 *$ & $0.1853^{*}$ & 1 & & & & & & \\
\hline leverage & (9) & $-0.1280^{*}$ & -0.0968 & -0.0646 & -0.0753 & -0.0222 & -0.0163 & -0.0065 & $0.2091 *$ & 1 & & & & & \\
\hline asset_growth & (10) & 0.0689 & -0.0258 & $0.2428 *$ & $-0.1402 *$ & 0.0684 & 0.0985 & -0.018 & $-0.1710^{*}$ & -0.0195 & 1 & & & & \\
\hline inefficieny & (11) & 0.1033 & $0.1666^{*}$ & -0.0419 & 0.0049 & -0.082 & -0.0484 & $-0.1272^{*}$ & $-0.2236^{*}$ & -0.0131 & 0.0275 & 1 & & & \\
\hline nploans & (12) & 0.1114 & -0.0235 & -0.1134 & -0.0582 & $-0.1439^{*}$ & $-0.3888^{*}$ & $-0.4556^{*}$ & $-0.1825^{*}$ & 0.0433 & $-0.1881 *$ & 0.0137 & 1 & & \\
\hline$G D P_{-}$growth & (13) & $-0.1370^{*}$ & -0.0134 & -0.0338 & -0.0153 & -0.0369 & 0.024 & $0.1295^{*}$ & -0.0817 & -0.0122 & $0.2019 *$ & 0.0016 & $-0.1541^{*}$ & 1 & \\
\hline interest_rate & (14) & $-0.2437 *$ & 0.016 & $-0.1114 *$ & -0.0063 & 0.0934 & 0.0459 & 0.0505 & $-0.1311 *$ & 0.0208 & -0.0055 & 0.0613 & 0.0276 & $0.0952^{*}$ & 1 \\
\hline
\end{tabular}

Significant correlation at the $1 \%$ level $(\mathrm{p}<0.01)$ is indicated by $*$. 